\title{
Análise Microbiológica em Presunto Cru de Cordeiro
}

Ítalo Abreu LIma (I), Hewerton Barbosa Gomes (I), Aline Pereira Martins (I), Henrique Pereira Cazedey (I), Roberta Hilsdorf Piccoli (I), Eduardo Mendes Ramos (I), Carolina Naves Aroeira (I)

(I) UFLA - Universidade Federal de Lavras (Caixa Postal 3037)

\section{Resumo}

A análise microbiológica é fundamental para se verificar quais e quantos microrganismos estão presentes e para conhecer as condições de higiene em que o alimento foi elaborado, os riscos que o oferece ao consumidor e se o alimento terá ou não vida útil pretendida. $\mathrm{O}$ trabalho teve como objetivo analisar a presença de microrganismos mesófilos e psicrotróficos na elaboração do presunto cru de carne ovina. Os presuntos foram elaborados pela técnica de salga a seco aplicada no pernil desossado de ovinos machos e fêmeas, provenientes da raça Santa Inês, abatidos com 60 dias de idade. As peças cárneas foram então adicionadas aos ingredientes: sal, açúcar, nitrito, nitrato, GDL e transglutaminase. Foram elaborados os Tratamentos (T1) sem adição de lactulose e (T2) com adição de lactulose. Os pedaços cárneos foram acomodadas em formas plásticas de $0,5 \mathrm{~kg}$ e mantidos sob refrigeração $\left(4^{\circ} \mathrm{C}\right)$ por 48 horas, para equalização. Em seguida foram removidos das formas, e levados para BOD $\left(4,0^{\circ} \mathrm{C}\right)$, por quatro dias, para uma pré-secagem. Após este período, as peças ficaram sob condições de temperatura $\left(16^{\circ} \mathrm{C}\right)$ e umidade relativa $(75-80 \% \mathrm{UR})$ controladas, para a maturação/secagem. As contagens do total de microrganismos psicrotróficos e mesófilos foram realizadas ao longo do processamento nos intervalos de tempo 0, 7, 21 e 30 dias. Foram preparadas diluições seriadas (até 10 -6) a partir de $25 \mathrm{~g}$ de amostra e 225 $\mathrm{ml}$ de água peptonada. Foi realizada à análise de microrganismos aeróbios mesófilos e psicrotróficos em duplicata em Ágar para contagem (PCA). Após a incubação $\left(35^{\circ} \mathrm{C} / 48 \mathrm{~h}\right)$ para mesófilos e $\left(7^{\circ} \mathrm{C} / 10\right.$ dias $)$ para

\footnotetext{
Referência:

Ítalo Abreu LIma, Hewerton Barbosa Gomes, Aline Pereira Martins, Henrique Pereira Cazedey, Roberta Hilsdorf Piccoli, Eduardo Mendes Ramos, Carolina Naves Aroeira. Análise Microbiológica em Presunto Cru de Cordeiro. In: Anais do 12을 Congresso Latinoamericano de Microbiologia e Higiene de Alimentos - MICROAL 2014 [= Blucher Food Science Proceedings, num.1, vol.1]. São Paulo: Editora Blucher, 2014. DOI 10.5151/foodsci-microal-170
} 
psicrotróficos realizou-se a contagem das colônias. O presuntos do tratamento 1 apresentaram ao longo do processamento contagem padrão de mesófilos variando de 4,8 x $105 \mathrm{UFC/g}$ ate $2,5 \times 109 \mathrm{UFC} / \mathrm{g}$ e para psicrotróficos valores entre 3,65 x $104 \mathrm{UFC/g}$ a 3,60 x $107 \mathrm{UFC/g}$. No tratamento 2 os resultados para mesófilos foi de 4,9 x $105 \mathrm{UFC} / \mathrm{g}$ a $2,5 \mathrm{x}$ $109 \mathrm{UFC} / \mathrm{g}$ e para psicrotróficos apresentaram contagens entre $6,15 \times 104$ UFC/g e 3,25 x $107 \mathrm{UFC/g}$ nos 4 tempos analisados. Apesar dos altos valores no trabalho, os tratamentos permitiram a elaboração de produtos acabados adequados para o consumo, pois como se trata de um produto curado que apresenta $\mathrm{pH}$ baixo, atividade de água de 0,92 e teor de sal acima de 3\%, permite que sejam armazenados à temperatura ambiente.

Palavras-Chave: carne ovina, Maturação, Prebiótico, Presunto cru Agência de Fomento: FAPEMIG (Fundação de Amparo à Pesquisa do estado de Minas Gerais) 